\title{
Synthesis of a New Chloro Antimony Complex with Pyridinium Derivative: Crystal Structure, Hirshfeld Surface Analysis, Vibrational, and Optical Properties
}

\author{
Nour Elleuch $^{1} \cdot$ Donia Fredj $^{1} \cdot$ Nassira Chniba-Boudjada $^{2} \cdot$ Mohamed Boujelbene $^{1}$
}

Received: 18 April 2019 / Accepted: 9 September 2019 / Published online: 17 September 2019

(c) The Author(s) 2019

\begin{abstract}
The new organic-inorganic hybrid material $\left(\mathrm{C}_{6} \mathrm{H}_{7} \mathrm{~N}_{2} \mathrm{~S}\right)_{2}\left[\mathrm{SbCl}_{4}\right] \mathrm{Cl}$ was synthesized by slow evaporation method and characterized by single-crystal X-ray diffraction, infrared absorption, Hirshfeld surface analysis, optical absorption and photoluminescence measurements. The Centro symmetric compound crystallizes in the triclinic system of space group P $\overline{1}$ with two formula units cell $(\mathrm{Z}=2)$.The crystal structure is composed of a discrete $\left[\mathrm{SbCl}_{4}\right]^{-}$anion and two isolated chloride $\mathrm{Cl}^{-}$anions which carried the same negative charge to balance the total charge of this compound surrounded by the 4 pyridiniumethioamide cations. Organic and inorganic parts which are linked by means of hydrogen bonding contacts $\mathrm{N}-\mathrm{H} \cdots \mathrm{Cl}$ with $\mathrm{N} \cdots \mathrm{Cl}$ length are varied in the range of 3.221-3.456 to form a Zero-dimensional network. The infrared study performed at room temperature charge in the $4000-400 \mathrm{~cm}^{-1}$ frequency regions confirms the existence of the organic cation $\left[\mathrm{C}_{6} \mathrm{H}_{7} \mathrm{~N}_{2} \mathrm{~S}\right]^{+}$and that of the $\left[\mathrm{SbCl}_{4}\right]^{-}$anion. The Photoluminescence spectrum exhibits a broad and strong band of luminescence located at $1.95 \mathrm{eV}(635 \mathrm{~nm})$, which can be even observed with the naked eye at room temperature and is due to exaction emission. The various intermolecular interactions of the two independent cations and six chloride atoms were examined via Hirshfeld surface analysis.
\end{abstract}

Keywords Antimony material $\cdot$ X-ray diffraction $\cdot$ Hirshfeld surfaces $\cdot$ Vibrational spectroscopy $\cdot$ Luminescence

\section{Introduction}

The group of halogenoantimonates (III) and halogenobismuthates (III) organic-inorganic hybrids are interesting systems because of the opportunity to associate the organic and the inorganic materials properties.

In fact, the coordination compounds of the main group metals which are characterized by their $\mathrm{ns}^{2}$ electronic lone pair at the metal, present a large variety of different

Electronic supplementary material The online version of this article (https://doi.org/10.1007/s10904-019-01316-8) contains supplementary material, which is available to authorized users.

Mohamed Boujelbene

m_boujelbene2010@yahoo.fr

1 Laboratoire Physico-Chimie de l'Etat Solide, LR11ES51, Faculté des Sciences de Sfax, Université de Sfax, Route de Soukra Km 3.5, BP 802, 3071 Sfax, Tunisia

2 Laboratoire de Cristallographie, CNRS, 25 Avenue des Martyrs, BP 166, 380 Grenoble, France structures. Among these complexes, the materials based on antimony (III) are good examples of this behavior. Nowadays, these compounds have received special attention for their various physical and chemical properties such as magnetic or ferroelectric transitions, conductivity (super conductivity), electroluminescence and photo-luminescence [1, 2]. In particular case of aromatic antimonate (III) chlorides, $\left[\mathrm{SbCl}_{4}\right]^{-}$anions are obtained [3, 4]. In these compounds, the metal shows a tendency towards distorted or regular tetrahedral coordination with some rather long $\mathrm{Sb}-\mathrm{Cl}$ bonds. This allows us to compare the relative importance of the stereo chemical activity of the lone electron pair on the $\mathrm{Sb}(\mathrm{III})$. Typically, chloro antimonates (III) expose a wide range of interactions and offer a unique possibility to compare the relative importance of the stereo chemical activity of the lone electron pair on the $\mathrm{Sb}(\mathrm{III})$ atom and $\mathrm{N}-\mathrm{H} \cdots \mathrm{Cl}$ hydrogen bonds [5]. These anionic species have been observed to form a variety of dimensionality. Indeed, the antimony halide often built up by distorted $\left[\mathrm{SbCl}_{6}\right]^{3-}$ octahedra or $\left[\mathrm{SbCl}_{4}\right]^{-}$tetrahedron, which can be isolated or connected with each other by corners, edges, or faces, thus forming 
naturally isolated molecules (0D) [6,7], infinite chains (1D) [8] or two dimensional (2D) networks. More than 30 various anionic structures have been isolated so far $[9,10]$. In these materials, the crystal packing is defined by the interaction between the two organic and inorganic entities, which can be hydrogen bonds, van der Waals, or electrostatic interactions. However, based on recent research works on organic-inorganic metal halides compounds taken as a support to study the effects of the size and the coordination mode of the cation, we have successfully synthesized a new Zero-dimensional organic-inorganic hybrid compound of the formula $\left(\mathrm{C}_{5} \mathrm{H}_{7} \mathrm{~N}_{2} \mathrm{~S}\right)_{2}\left[\mathrm{SbCl}_{4}\right] \mathrm{Cl}$. This research work reports the chemical synthesis, structure characterization by $\mathrm{X}$-ray diffraction, infrared spectroscopy (IR), and optical (photoluminescence and absorption) properties of the 4 pyridiniumethioamide chloride tetrachloro antimonates (III).

\section{Experimental}

\subsection{Synthesis}

Under ambient conditions, the title compound $\left(\mathrm{C}_{6} \mathrm{H}_{7} \mathrm{~N}_{2}\right)_{2}\left[\mathrm{SbCl}_{4}\right] \mathrm{Cl}$ was synthesized by dissolving in about $10 \mathrm{ml}$ of distillated water each one of 4 pyridinethioamide $\mathrm{C}_{6} \mathrm{H}_{6} \mathrm{~N}_{2} \mathrm{~S}(0.27 \mathrm{mg}, 97 \%)$ and Antimony trichloride $\mathrm{SbCl}_{3}(0.228 \mathrm{mg}, 99.5 \%)$ which were purchased from Sigma-Aldrich and used without further purification. Then, these latter were mixed in the 2:1 stoichiometric ratio in a concentrated $\mathrm{HCl}(37 \%, 3 \mathrm{ml})$ as shown in the following reaction:

$2\left(\mathrm{C}_{6} \mathrm{H}_{6} \mathrm{~N}_{2} \mathrm{~S}\right)+\mathrm{SbCl}_{3}+2 \mathrm{HCl} \stackrel{\mathrm{H}_{2} \mathrm{O}}{\longrightarrow}\left(\mathrm{C}_{6} \mathrm{H}_{7} \mathrm{~N}_{2} \mathrm{~S}\right)_{2}\left[\mathrm{SbCl}_{4}\right] \mathrm{Cl}$

The resulting aqueous solution was then kept to evaporate at room temperature for about 4 weeks, leading to the growth of yellow crystals of $\left(\mathrm{C}_{6} \mathrm{H}_{7} \mathrm{~N}_{2} \mathrm{~S}\right)_{2}\left[\mathrm{SbCl}_{4}\right] \mathrm{Cl}$.

\subsection{Hirshfeld Surface Calculations}

Hirshfeld surfaces analyses [11] and their associated twodimensional fingerprint plots as a powerful tool leads not only to study the solid-state behavior of molecules, but also to qualify the different types of inter-molecular inter-actions in the title compound. Molecular Hirshfeld surfaces, which were generated by the Crystal Explorer program [12, 13], were constructed from CIF file in order to analyze crystal structures.

Molecular Hirshfeld surfaces are built based on the distribution of electrons calculated as the sum of spherical atom electron densities $[14,15]$. Moreover, the $d_{\text {norm }}$ normalized contact distance property between molecules in 3D space based on both $\mathrm{d}_{\mathrm{i}}$ and $\mathrm{d}_{\mathrm{e}}$ (The distance from Hirshfeld surface to the nearest nucleus inside and outside, respectively) and the van der Waals radii ( $\mathrm{ri}^{\mathrm{dvW}}$ and $\mathrm{re}^{\mathrm{dvW})}$ of the atoms given by the following equation: $[16,17]$.

$d_{\text {norm }}=\frac{d_{i}-r_{i}^{v d w}}{r_{i}^{v d w}}+\frac{d_{e}-r_{e}^{v d w}}{r_{e}^{v d w}}$

Therefore, the values of $d_{\text {norm }}$ can be negative or positive when intermolecular contacts were shorter or longer than "rvdw", respectively.

The 3D $d_{\text {norm }}$ surfaces were visualized using a red-white-blue color scheme as follows; the first one indicates a negative $\mathrm{d}_{\text {norm }}$ value; and a shorter intermolecular contact than $\sum r^{v d w}$, the second represents the distance close to van de Waals contacts with zero $\mathrm{d}_{\text {norm }}$ values, and the last one shows positive $\mathrm{d}_{\text {norm }}$ values and a longer intermolecular contact than $\sum r^{v d w}$. The combination of $d_{\mathrm{e}}$ and $d_{\mathrm{i}}$ in the form of a 2D fingerprint plot [18] ensures the summary of intermolecular contacts in the crystal and are in complement to the Hirshfeld surfaces [19]. Two additional colored properties (shape index and curvedness) based on the local curvature of the surface can also be specified [20]. The present research works adopt the Hirshfeld surfaces analysis which are mapped with $d_{\text {norm }}$, shape-index, curvedness and 2D fingerprint plots (full and resolved) and performed by the Crystal-Explorer program [21].

\subsection{Infrared Measurements}

To gain more information within the crystal structure, we have undertaken a vibrational study using the Fourier transform infrared (FT-IR) absorption at room temperature, which was performed, in a Perkin-Elmer FT-IR Paragon $1000 \mathrm{PC}$ spectrometer over the $4000-400 \mathrm{~cm}^{-1}$ range, in a $\mathrm{KBr}$ pellet.

\subsection{Absorption and Photoluminescence Measurements}

The photoluminescence spectrum of $\left(\mathrm{C}_{6} \mathrm{H}_{7} \mathrm{~N}_{2} \mathrm{~S}\right)_{2}\left[\mathrm{SbCl}_{4}\right] \mathrm{Cl}$ was reported at room temperature in which we utilized a PerkinElmer LS 55 spectrometer within a $350 \mathrm{~nm}$ radiation.

The optical absorption spectrum was resolute from transmission measurements performed using Cary 5000 UV-Vis-NIR spectrophotometer.

\subsection{X-ray Crystallography}

A new single crystal was mounted at $293 \mathrm{~K}$ on a Bruker ApexII Kappa CCD diffractometer using AgKa radiation $(\lambda=0.5608 \AA)$. A number of 28,517 reflections were measured, out of which 4650 were independent and 4211 had 
Table 1 Crystal data and experimental parameters used for the intensity data collection strategy and final results of the structure determination

\begin{tabular}{|c|c|}
\hline Chemical formula & $\left(\mathrm{C}_{5} \mathrm{~N}_{2} \mathrm{H}_{7} \mathrm{~S}\right)_{2}\left[\mathrm{SbCl}_{4}\right] \mathrm{Cl}$ \\
\hline Formula weight $\left(\mathrm{g} \mathrm{mol}^{-1}\right)$ & 874.38 \\
\hline Crystal system, space group & Triclinic, $\mathrm{P} \overline{1}$ \\
\hline Temperature & $293 \mathrm{~K}$ \\
\hline$a(\AA)$ & $9.502(5)$ \\
\hline$b(\AA)$ & $10.461(5)$ \\
\hline$c(\AA)$ & $12.262(5)$ \\
\hline$\alpha\left({ }^{\circ}\right)$ & $115.250(5)$ \\
\hline$\beta\left(^{\circ}\right)$ & $109.376(5)$ \\
\hline$\gamma\left({ }^{\circ}\right)$ & $90.251(5)$ \\
\hline Cell volume $\left(\AA^{3}\right)$ & $1024.6(8)$ \\
\hline $\mathrm{Z}$ & 2 \\
\hline$F(000)$ & 832 \\
\hline Density & 2.834 \\
\hline$\mu\left(\mathrm{mm}^{-1}\right)$ & 2.16 \\
\hline Radiation type, $\lambda(\AA)$ & $\operatorname{Ag} K \alpha, 0.56087$ \\
\hline $\mathrm{R}_{\mathrm{int}}$ & 0.055 \\
\hline$\Theta$ range $\left({ }^{\circ}\right)$ & $2.7-21.4$ \\
\hline \multirow[t]{3}{*}{ Indexes range } & $-12 \leq \mathrm{h} \leq 12$ \\
\hline & $-13 \leq \mathrm{k} \leq 13$ \\
\hline & $-15 \leq 1 \leq 15$ \\
\hline Measured reflections & 28,517 \\
\hline Independent reflections & 4650 \\
\hline Reflection with $\mathrm{I}>2 \sigma(I)$ & 4211 \\
\hline $\mathrm{R}[\mathrm{F} 2>2 \sigma(\mathrm{F} 2)]$ & 0.054 \\
\hline$w R\left(F^{2}\right)$ & 0.175 \\
\hline Goof $S\left(F^{2}\right)$ & 1.04 \\
\hline$\Delta \rho_{\max } / \Delta \rho_{\min }\left(\mathrm{e} \AA^{-3}\right)$ & $2.73 /-3.15$ \\
\hline Summary of data CCDC & $1,888,302$ \\
\hline
\end{tabular}

intensity I $>2 \sigma(\mathrm{I})$. The crystal structure was solved by direct methods using the program SHELXS-2013 [22]. However, the antimony atoms were determined by the method of Patterson with SHELXS-2013 program [22], while the other atoms such as the organic moieties were found from successive Fourier calculations using SHELXL-2013 [23]. The hydrogen atoms of the $\mathrm{CH}, \mathrm{NH}$ and $\mathrm{NH}_{2}$ groups were fixed geometrically by the appropriate instructions of the program (AFIX 43, AFIX 43 and AFIX 93, respectively) [23]. After performing several refinement tests, we found that the final discrepancy factors $\mathrm{R} 1=0.055$ and WR2 $=0.175$. The drawings were made with Diamond [24].

The crystallographic data for $\left(\mathrm{C}_{6} \mathrm{H}_{7} \mathrm{~N}_{2} \mathrm{~S}\right)_{2}\left[\mathrm{SbCl}_{4}\right] \mathrm{Cl}$ are summarized in Table 1 . The hydrogen bonding parameters are represented in Table 2. The interatomic distances and bonds angles are listed in Table S1. A summary of atomic coordinates with Ueq is given in Table S2.
Table 2 Hydrogen-bonds geometry (Á)

\begin{tabular}{llllll}
\hline $\mathrm{D}-\mathrm{H}$ & $\mathrm{d}(\mathrm{D}-\mathrm{H})$ & $\mathrm{d}(\mathrm{H} \cdots \mathrm{A})$ & $\langle\mathrm{DHA}\rangle$ & $\mathrm{d}(\mathrm{D} \cdots \mathrm{A})$ & $\mathrm{A}$ \\
\hline N2-H2A & 0.860 & 2.542 & 136.51 & 3.221 & $\mathrm{Cl1}$ \\
$\mathrm{N} 4-\mathrm{H} 4 \mathrm{~A}$ & 0.860 & 2.548 & 137.04 & 3.231 & $\mathrm{C} 14$ \\
$\mathrm{~N} 3-\mathrm{H} 3$ & 0.860 & 2.958 & 114.38 & 3.405 & $\mathrm{C} 14$ \\
$\mathrm{~N} 3-\mathrm{H} 3$ & 0.860 & 2.561 & 155.08 & 3.360 & $\mathrm{C} 15$ \\
$\mathrm{~N} 1-\mathrm{H} 1$ & 0.860 & 2.947 & 115.51 & 3.407 & $\mathrm{C} 11$ \\
$\mathrm{~N} 1-\mathrm{H} 1$ & 0.860 & 2.579 & 154.50 & 3.376 & $\mathrm{C} 16$ \\
\hline
\end{tabular}

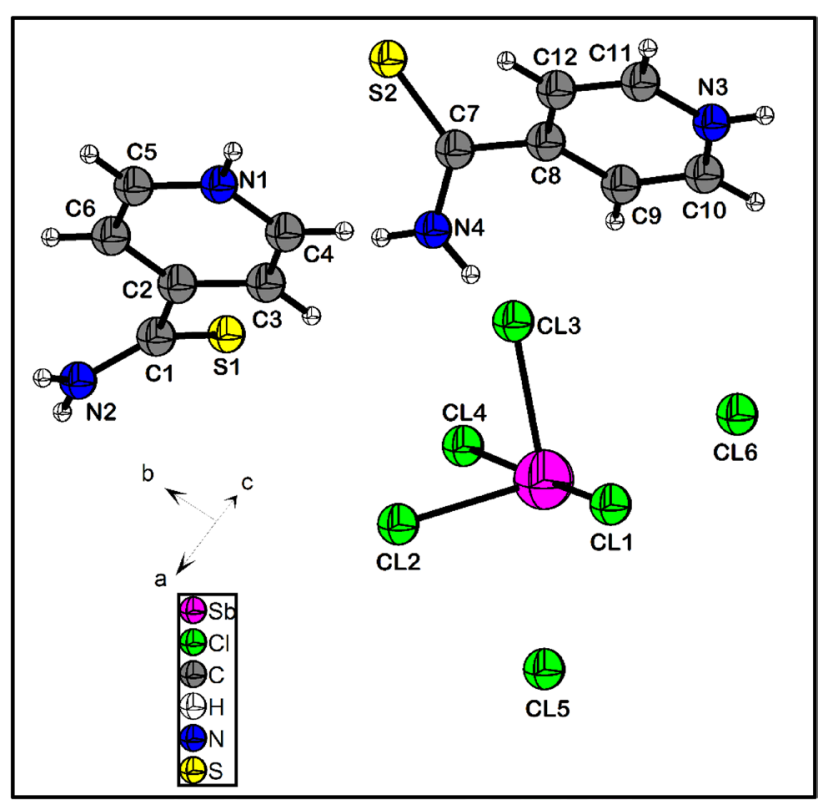

Fig. 1 Asymmetric unit of the $\left(\mathrm{C}_{6} \mathrm{H}_{7} \mathrm{~N}_{2} \mathrm{~S}\right)_{2}\left[\mathrm{SbCl}_{4}\right] \mathrm{Cl}$ crystal

\section{Results and Discussion}

\subsection{Crystallographic Study}

The results of single-crystal X-ray diffraction analysis at room temperature reveal that the title compound crystallizes in the centrosymmetric triclinic $\mathrm{P} \overline{1}$ space group. The cell dimensions are: $\mathrm{a}=9.5018$ (5) $\AA, \mathrm{b}=10.4618$ (5) $\AA$, $c=12.2616(5) \AA, \alpha=115.2500(5)^{\circ}, \beta=109.3762(5)^{\circ}$, $\gamma=90.2513(5)^{\circ}$ and $V=1024.6(8) \AA^{3}$.

The asymmetric unit of $\left(\mathrm{C}_{5} \mathrm{H}_{7} \mathrm{~N}_{2}\right)_{2}\left[\mathrm{SbCl}_{4}\right] \mathrm{Cl}$ is made up of the part of anions which is composed of a tetrachloride antimonite and two isolated chloride $\mathrm{Cl}^{-}$anions, and the part of cations formed by two independent 4 pyridiniumethioamide organic cations (Fig. 1). Furthermore, these cations are interposed between the inorganic sheets forming zigzag chains (Fig. 4) which are linked via hydrogen bonds $\mathrm{N}-\mathrm{H} \cdots \mathrm{Cl}$ with $\mathrm{N} \cdots \mathrm{Cl}$ length in the range of 3.221-3.456 (Table 2). 


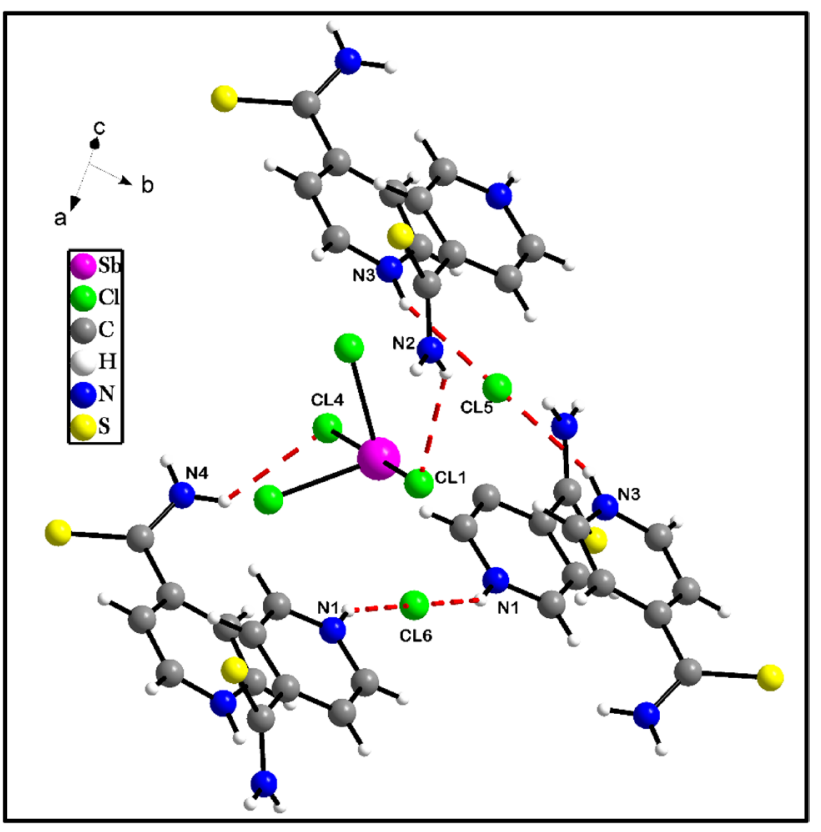

Fig. 2 The environment of the inorganic entities

In this atomic arrangement, the central antimony atom is surrounded by four chlorine atoms forming a regular $\left[\mathrm{SbCl}_{4}\right]^{-}$tetrahedral that are located at $\mathrm{x}=1 / 4$ and $\mathrm{x}=3 / 4$, They are also isolated from each other to form a Zero-dimensional network. Moreover, the geometry of the $\mathrm{SbCl}_{4}$ tetrahedral chlorine coordination is characterized by a range of $\mathrm{Sb}-\mathrm{Cl}$ bond length from 2.418(16) to 2.605(2) $\AA$ (Table S1) to build a regular tetrahedron according to the result of distortion index [25] (Table S3):

$\mathrm{ID}(\mathrm{Sb}-\mathrm{Cl})=1 / 4 \sum_{1}^{4}\left(\frac{\mathrm{SbCli}-\mathrm{SbClm}}{\mathrm{SbClm}}\right)=0$

Table $\mathrm{S} 1$ generates the four $\mathrm{Sb}-\mathrm{Cl}$ bonds ranging from 2.418 to $2.605 \AA$. The two longest ones (2.605 and 2.602 $\AA$ ) correspond to $(\mathrm{Cl}(1))$ and $\mathrm{Cl}(4)$, respectively. They are linked via the hydrogen bonds with the nitrogen atom $(\mathrm{N}(2))$ and $\mathrm{N}(4)$ of 4 pyridiniumethioamide cation forming the shortest hydrogen bond $\mathrm{N}(2)-\mathrm{H} \cdots \mathrm{Cl}(1)=3.221 \AA$ and $\mathrm{N}(4)-\mathrm{H} \cdots \mathrm{Cl}(4)=3.231 \AA$ in this structure Table 2 .

Figure 2 shows that anion part is surrounded by five cations where the $\mathrm{SbCl}_{4}$ anion interconnected with one cation via hydrogen bond $\mathrm{N}(2)-\mathrm{H} \cdots \mathrm{Cl}(1)$ whereas each chlorine of $\mathrm{Cl} 6$ and $\mathrm{Cl} 5$ is surrounded by two 4 pyridiniumethioamide via hydrogen bonds which are $\mathrm{N}(3)-\mathrm{H} \cdots \mathrm{Cl} 5$ and $\mathrm{N}(1)-\mathrm{H} \cdots \mathrm{Cl} 6$.

A projection of the structure on the (001) plane (Fig. 3) indicates that the inorganic clusters and $\left[\mathrm{C}_{6} \mathrm{H}_{7} \mathrm{~N}_{2} \mathrm{~S}\right]^{+}$cations form alternating layers parallel to $(\mathrm{a}, \mathrm{b})$ plans, which are located at approximately $x=1 / 4$ and $x=3 / 4$ (Fig. 5).

It is evident that the intermolecular hydrogen bonding contacts $\mathrm{N}-\mathrm{H} \cdots \mathrm{Cl}$ and the van der Waals contacts can give rise to a Zero-dimensional construction and add to stabilities.

Additionally, the free chloride anions $\mathrm{Cl} 6$ and $\mathrm{Cl} 5$ occupy the corners at $\mathrm{x}=0$ and the middle of the edge $\mathrm{x}=1 / 2$, respectively. Figures 3 and 4 show that the first one provides a linkage between two successive and similar chains
Fig. 3 The atomic arrangement of $\left(\mathrm{C}_{6} \mathrm{H}_{7} \mathrm{~N}_{2} \mathrm{~S}\right)_{2}\left[\mathrm{SbCl}_{4}\right] \mathrm{Cl}$ in projection along the c-axis

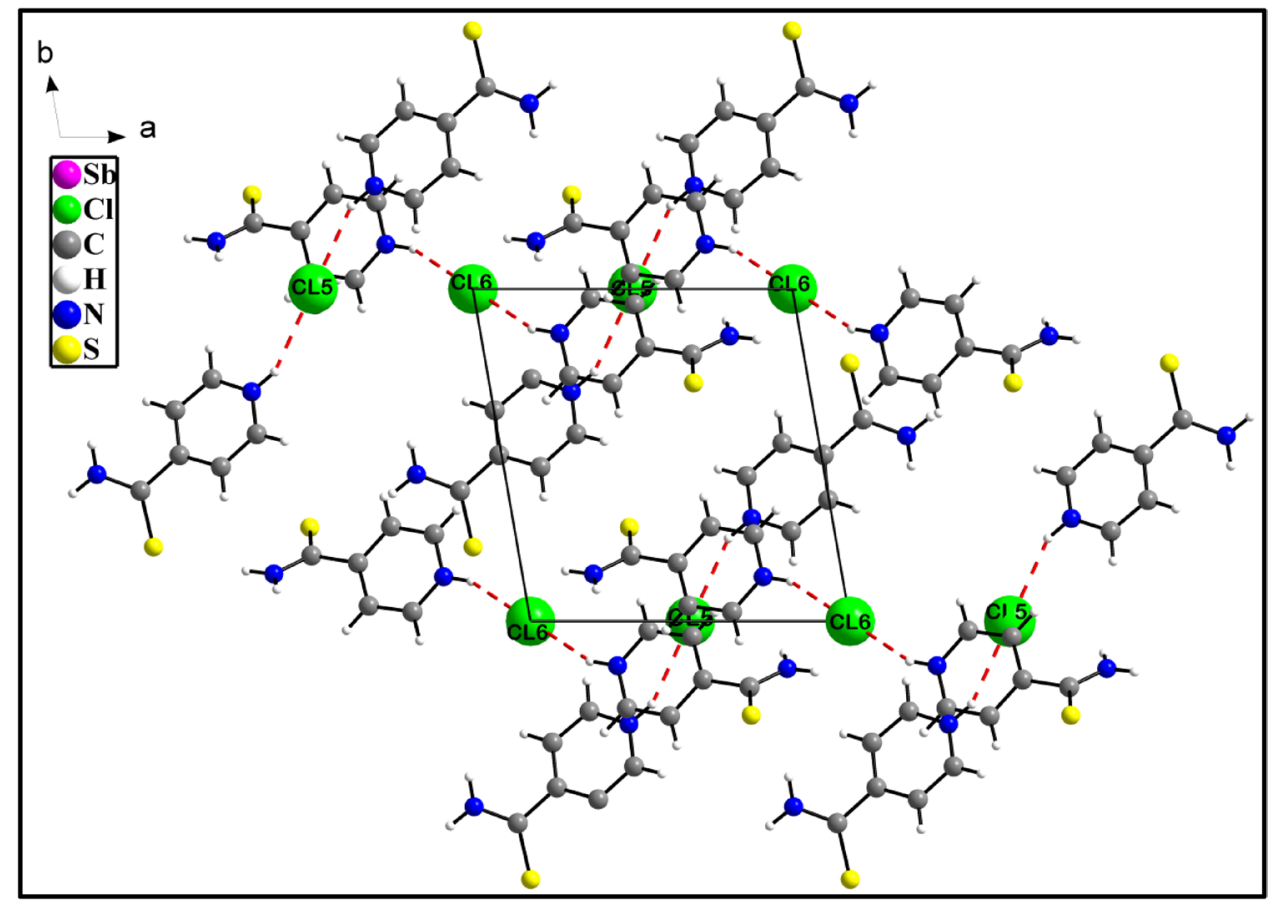


of 4 pyridiniumethioamide but the second one insures the connection between two cations into the chains.

Moreover, the molecular packing is dominated by hydrogen bonds interactions of the aforementioned type, which are formed by an intertial $\mathrm{Cl}$ atom (Cl6) and (Cl5) with 4 pyridiniumethioamide cations $\mathrm{N}(1) \cdots \mathrm{Cl}(6) 3.376 \AA$ and $\mathrm{N}(3) \cdots \mathrm{Cl}(5) 3.360 \AA$.

The charge of the anionic sub lattice $\left(\left[\mathrm{SbCl}_{4}\right]^{-} \mathrm{Cl}_{2}{ }^{-}\right)$is balanced by the presence of two independent cations each of which is mono-protonated $\left[\mathrm{C}_{6} \mathrm{H}_{7} \mathrm{~N}_{2} \mathrm{~S}\right]^{+}$. Indeed, the two chlorine anions share the same negative charge (Fig. 5, Table S2).

On the other hand, the organic cations are intercalating in the interlayer spacing and neutralize the negative charge of the inorganic layers. Furthermore, the distance between two aromatic nucleus was $6.617 \AA>3.8 \AA$ (Fig. 6), which confirms that the $\pi-\pi$ interaction are absent in this compound [26].

\subsection{Infrared Spectroscopy}

To gain more information about the structure of the title compound $\left(\mathrm{C}_{6} \mathrm{H}_{7} \mathrm{~N}_{2} \mathrm{~S}\right)_{2}\left[\mathrm{SbCl}_{4}\right] \mathrm{Cl}$, we performed a vibrational study using infrared absorption as shown in Fig. S1.

According to some studies reported in the literature [2, 27-35] we can propose an attempt of assignment of the observed bands Table 3 .

The IR spectrum shows, at high wave numbers, the $\mathrm{N}-\mathrm{H}$ stretching modes, combination bands and harmonics, whereas at lower ones, it indicates the bending and external modes. However, numerous functional groups such as $\mathrm{NH}, \mathrm{C}-\mathrm{H}, \mathrm{C}-\mathrm{C}, \mathrm{C}-\mathrm{N}, \mathrm{C}-\mathrm{C}-\mathrm{N}$ and $\mathrm{C}-\mathrm{N}-\mathrm{C}$ are present in 4 pyridiniumethioamide cation, which are manifested in different range with different intensity (Fig. S1). The absorption bands observed at 3507 and $3329 \mathrm{~cm}^{-1}$ are attributed to the stretching asymmetric and symmetric $\mathrm{v}\left(\mathrm{NH}_{2}\right)$, respectively $[28,34]$. However, scissoring asymmetric and symmetric vibration $\delta\left(\mathrm{NH}_{2}\right)$ have been identified as broad and weak bands at 1717 and $1684 \mathrm{~cm}^{-1}$, respectively [28, 34]. The bands at 1278, 692 and $674 \mathrm{~cm}^{-1}$ correspond to twisting $\mathrm{NH}_{2}$ [29] and the band at $614 \mathrm{~cm}^{-1}$ is due to wagging $\left(\mathrm{NH}_{2}\right)$ [30]. Concerning the asymmetric stretching vibrations of the $\mathrm{N}-\mathrm{H}$ bond, they appear at 3507, 1700 and $1684 \mathrm{~cm}^{-1}$ whereas the absorptions bands situated at 3329 and $1635 \mathrm{~cm}^{-1}$ correspond to the symmetric stretching vibration of the $\mathrm{N}-\mathrm{H}$ bond (Fig. S1). Moreover, the broad band observed in the 2991-2685 $\mathrm{cm}^{-1}$ spectral region, corresponds to the NH stretching vibrations interconnected by a system of hydrogen bonds in the crystal [28, 32, 34].

Generally, in the caption 4 pyridiniumethioamide, the stretching vibrations $\mathrm{C}-\mathrm{H}$ are detected in the region $2787-3133 \mathrm{~cm}^{-1}$ [28-32]. These vibrations are observed in IR at $3133,2991,2869$ and $2787 \mathrm{~cm}^{-1}$, where the two bands

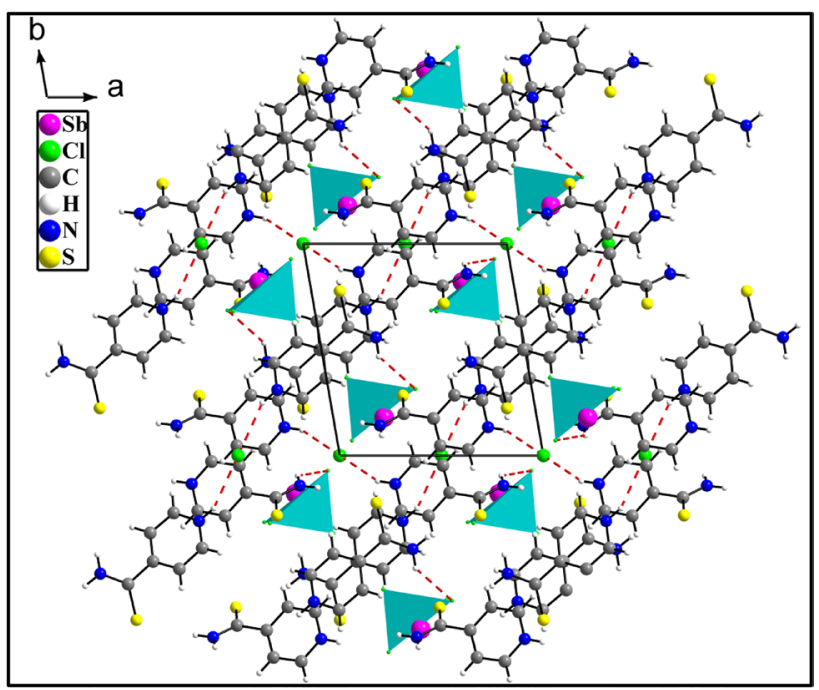

Fig. 4 Hydrogen bonds between Free chlorine and organic entities in the crystal structure of $\left(\mathrm{C}_{6} \mathrm{H}_{7} \mathrm{~N}_{2} \mathrm{~S}\right)_{2}\left[\mathrm{SbCl}_{4}\right] \mathrm{Cl}$ in projection along the c-axis. (H-bonds are represented by dashed lines)

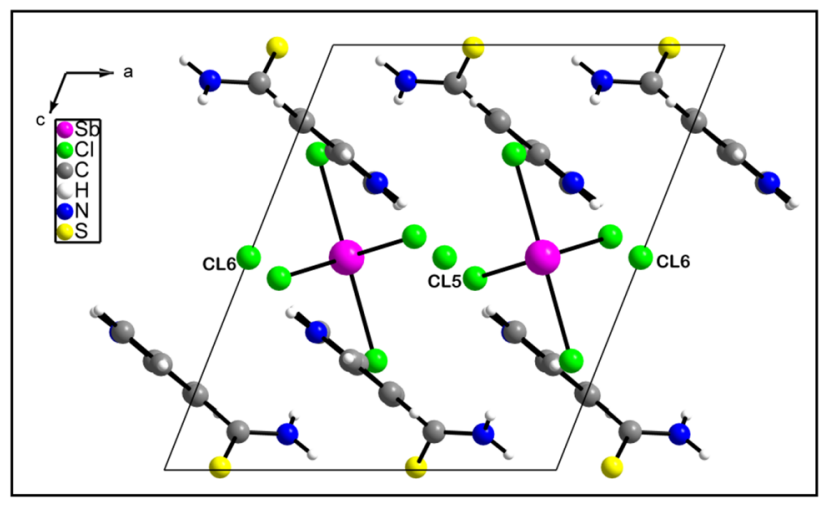

Fig. 5 The atomic arrangement of $\left(\mathrm{C}_{6} \mathrm{H}_{7} \mathrm{~N}_{2} \mathrm{~S}\right)_{2}\left[\mathrm{SbCl}_{4}\right] \mathrm{Cl}$ in projection along the b-axis

at $2904,2869 \mathrm{~cm}^{-1}$ are attributed to the $(\mathrm{C}-\mathrm{H})$ asymmetric and symmetric stretching vibrations, respectively $[33,34]$.

Besides, the bands situated at 1204 and $1056 \mathrm{~cm}^{-1}$ were assigned to the in-plane bending (C-H) (Fig. S1). The vibrations at $1003 \mathrm{~cm}^{-1}$ are due to the scissoring mode of the $\mathrm{N}-\mathrm{H}$ bands.

Additionally, the $\mathrm{C}=\mathrm{C}$ stretching modes are superimposed in 1457,1408 and $1388 \mathrm{~cm}^{-1}$. Besides, the $\mathrm{C}-\mathrm{N}$ asymmetric stretching modes are localized at $1129 \mathrm{~cm}^{-1}$ while $\mathrm{C}-\mathrm{N}$ symmetric stretching mode was situated at $1232 \mathrm{~cm}^{-1}$. The scissoring modes of the three bands $\mathrm{C}-\mathrm{N}-\mathrm{H}, \mathrm{C}-\mathrm{C}-\mathrm{C}$ and $\mathrm{C}-\mathrm{C}-\mathrm{N}$ are observed at 1003,464 and $446 \mathrm{~cm}^{-1}$, respectively $[31,36]$. The out-of-plane bending of $(\mathrm{C}-\mathrm{C}-\mathrm{H})$ and $\mathrm{C}-\mathrm{H}$ occurred at 845 and $812 \mathrm{~cm}^{-1}$, respectively, as a medium peak [29]. Finally, the frequencies in the ranges of 


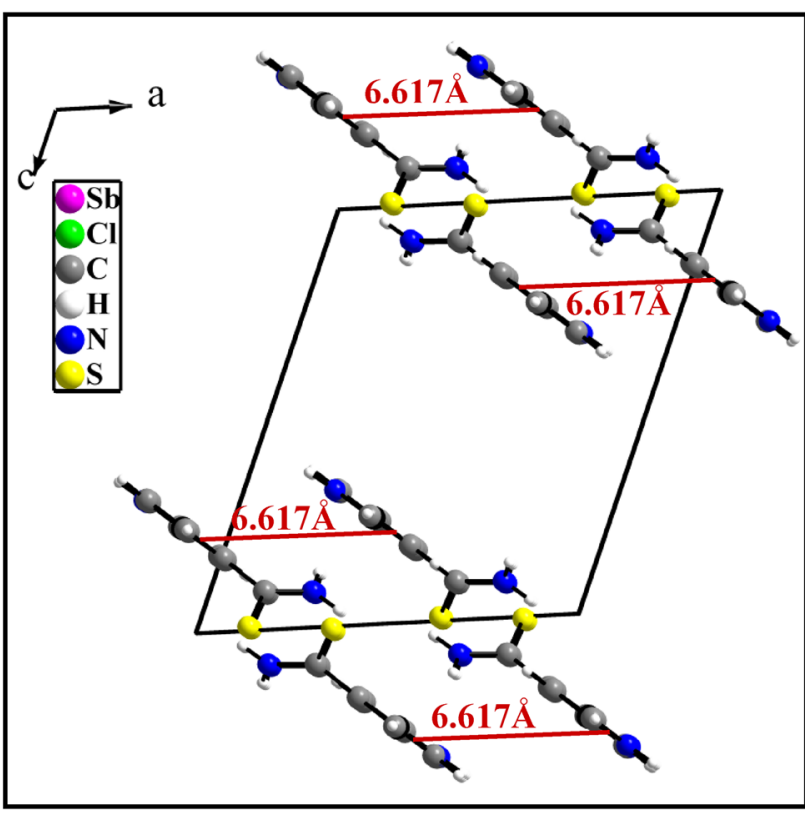

Fig. 6 Offset-face-to-face interactions motifs in the cation-cation chains in the plane $(a b)$

$970-518 \mathrm{~cm}^{-1}$ and $764-416 \mathrm{~cm}^{-1}$ are attributed to the scissoring bending modes of $\mathrm{C}-\mathrm{C}, \mathrm{C}-\mathrm{N}$ and $\mathrm{C}-\mathrm{NH}_{2}[31,33,34]$.

\subsection{Optical Study}

The optical properties of 4 pyridiniumethioamide chloride tetrachloroantimonates (III) were evaluated by the UV-Vis absorption and photoluminescence studies at room temperature. The obtained spectra are shown in Fig. 7, indicating that the $\left(\mathrm{C}_{6} \mathrm{~N}_{2} \mathrm{H}_{7} \mathrm{~S}\right)_{2}\left[\mathrm{SbCl}_{4}\right] \mathrm{Cl}$ exhibits two distinct absorption bands around $4.01 \mathrm{eV}(310 \mathrm{~nm})$ and $4.36 \mathrm{eV}(285 \mathrm{~nm})$ which are attributed to the metal charge transfer (LMCT) transition from the $3 p$ orbital of $\mathrm{Cl}$ to $5 p$ orbital of $\mathrm{Sb}(\mathrm{III})$ as described in previous outputs [35, 37-39]. On the other hand, the photoluminescence spectrum Fig. 7 shows a broad and strong emission band at $1.95 \mathrm{eV}(635 \mathrm{~nm})$, which can be even observed with the naked eye at room temperature and which is due to exciton emission $[31,36]$. In the antimony (III) chloride based hybrids, the lowest exciton state arises from excitations between the valence band, which consists of a mixture of $\mathrm{Sb}(5 \mathrm{~s})$ and $\mathrm{Cl}(3 \mathrm{p})$ states. Besides, the conduction band derives primarily from $\mathrm{Sb}(5 \mathrm{p})$ states, and is confined zero-dimensionally network in the $\left[\mathrm{SbCl}_{4}\right]^{-1}$ tetrahedron, which suggests that the material behaves as semiconductor and is consistent with the yellow color of the cristal.
Table 3 Experimental frequencies $\left(\mathrm{cm}^{-1}\right)$ of the $\left(\mathrm{C}_{5} \mathrm{H}_{7} \mathrm{~N}_{2} \mathrm{~S}\right)_{2}\left[\mathrm{SbCl}_{4}\right]$ $\mathrm{Cl}$ compound

\begin{tabular}{|c|c|}
\hline Observed FT-IR $\left(\mathrm{cm}^{-1}\right)$ & Attributions \\
\hline $3329 \mathrm{~m}$ & $\mathrm{v}_{\mathrm{s}}\left(\mathrm{NH}_{2}\right)$ \\
\hline $3133 \mathrm{~m}$ & $v(\mathrm{C}-\mathrm{H})$ \\
\hline $2991 \mathrm{~m}$ & $\mathrm{v}(\mathrm{N}-\mathrm{H} \cdots \mathrm{Cl})$ \\
\hline $2904 \mathrm{~m}$ & $\mathrm{v}_{\mathrm{as}}(\mathrm{C}-\mathrm{H})$ \\
\hline $2869 \mathrm{vw}$ & $\mathrm{v}_{\mathrm{s}}(\mathrm{C}-\mathrm{H})$ \\
\hline $2787 \mathrm{~m}$ & $v(\mathrm{C}-\mathrm{H})$ \\
\hline $2685 \mathrm{vw}$ & $\mathrm{v}(\mathrm{N}-\mathrm{H} \cdots \mathrm{Cl})$ \\
\hline $1717 \mathrm{vw}$ & $\delta_{\mathrm{as}}\left(\mathrm{NH}_{2}\right)$ \\
\hline $1684 \mathrm{~m}$ & $\delta_{\mathrm{as}}\left(\mathrm{NH}_{2}\right)$ \\
\hline $1635 \mathrm{~m}$ & $\delta(\mathrm{N}-\mathrm{H})$ \\
\hline $1580 \mathrm{bw}$ & $\delta(\mathrm{N}-\mathrm{H})$ \\
\hline 1494 bw & $\beta(\mathrm{N}-\mathrm{H})$ \\
\hline $1457 \mathrm{bw}$ & $v(\mathrm{C}=\mathrm{C})$ \\
\hline $1408 \mathrm{bw}$ & $v(C=C)$ \\
\hline $1388 \mathrm{~m}$ & $v(C=C)$ \\
\hline $1339 \mathrm{~m}$ & $v_{a s}(\mathrm{C}-\mathrm{N})$ \\
\hline $1278 \mathrm{~s}$ & $\mathrm{t}\left(\mathrm{NH}_{2}\right)$ \\
\hline $1232 \mathrm{~s}$ & $v_{s}(C-N)$ \\
\hline $1204 \mathrm{~m}$ & $\beta(\mathrm{C}-\mathrm{H})$ \\
\hline 1129 bw & $v(\mathrm{C}-\mathrm{N})$ \\
\hline $1087 \mathrm{bw}$ & $\mathrm{v}_{\mathrm{as}}(\mathrm{C}-\mathrm{C}-\mathrm{N})$ \\
\hline $1056 \mathrm{bw}$ & $\beta(\mathrm{C}-\mathrm{H})$ \\
\hline $1025 \mathrm{bw}$ & $v_{s}(C-C)$ \\
\hline $1003 \mathrm{~m}$ & $\delta(\mathrm{C}-\mathrm{N}-\mathrm{H})$ \\
\hline $970 \mathrm{~m}$ & $\delta(\mathrm{C}-\mathrm{C})$ \\
\hline $845 \mathrm{~s}$ & $\gamma(\mathrm{C}-\mathrm{C}-\mathrm{H})$ \\
\hline $812 \mathrm{~s}$ & $\gamma(\mathrm{C}-\mathrm{H})$ \\
\hline $764 \mathrm{~s}$ & $\delta(\mathrm{C}-\mathrm{N})$ \\
\hline $734 \mathrm{~m}$ & $\gamma(\mathrm{C}-\mathrm{H})$ \\
\hline $729 \mathrm{vw}$ & $\gamma(\mathrm{C}-\mathrm{C}-\mathrm{C})$ \\
\hline $650 \mathrm{vw}$ & $\delta(\mathrm{C}-\mathrm{C})$ \\
\hline $692 \mathrm{vw}$ & $\mathrm{t}\left(\mathrm{NH}_{2}\right)$ \\
\hline $674 \mathrm{~m}$ & $\mathrm{t}\left(\mathrm{NH}_{2}\right)$ \\
\hline $614 \mathrm{bw}$ & $\omega\left(\mathrm{NH}_{2}\right)$ \\
\hline $565 \mathrm{bw}$ & $\delta(\mathrm{C}-\mathrm{C}=\mathrm{C})$ \\
\hline $518 \mathrm{vw}$ & $\delta(\mathrm{C}-\mathrm{C})$ \\
\hline $464 \mathrm{vw}$ & $\delta(\mathrm{C}-\mathrm{C}-\mathrm{C})$ \\
\hline $446 \mathrm{vw}$ & $\delta(\mathrm{C}-\mathrm{C}-\mathrm{N})$ \\
\hline $416 \mathrm{vw}$ & $\omega(\mathrm{N}-\mathrm{H})+\delta\left(\mathrm{C}-\mathrm{NH}_{2}\right)$ \\
\hline
\end{tabular}

$s$ Strong, $w$ weak, $v$ very, $b$ broad, $m$ medium, $v$ stretching, $\beta$ in plane bending, $\delta$ scissoring, $\omega$ wagging, $t$ twisting, $\gamma$ out of plane bending

\subsection{Molecular Hirshfeld Surfaces Analysis}

The Hirshfeld surfaces has been conducted to explore the type of interactions $(\mathrm{C}-\mathrm{H} \cdots \pi, \mathrm{H} \cdots \mathrm{H}, \mathrm{C} \cdots \mathrm{C}$ etc. $)$ as well as to study the various intermolecular interactions that play an important role in a molecular crystal. The molecular 
Fig. 7 UV-Visible optical absorption (a) and Photoluminescence $(b)$ spectrum of $\left(\mathrm{C}_{6} \mathrm{H}_{7} \mathrm{~N}_{2} \mathrm{~S}\right)_{2}\left[\mathrm{SbCl}_{4}\right] \mathrm{Cl}$

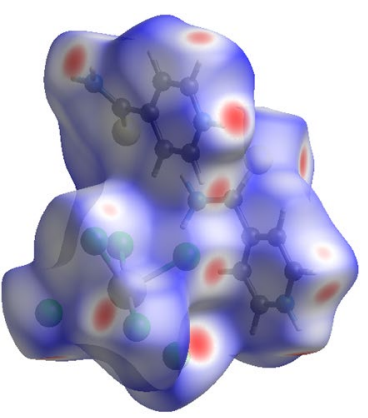

(a)

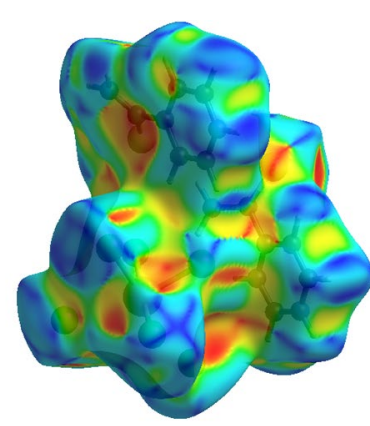

(b)

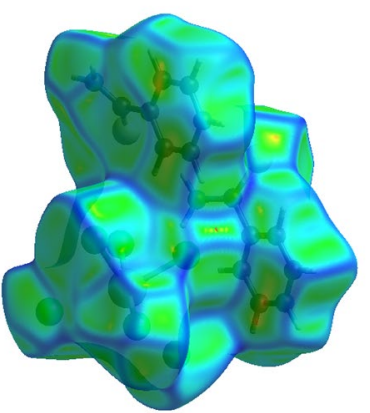

(c)

Fig. 8 Hirshfeld surfaces of 4 pyridinumethioamide dichloride tetrachloroantimonates(III): a $3 \mathrm{D} \mathrm{d}_{\text {norm }}$ surface, b surface index, c curvedness

Hirshfeld surface; $3 \mathrm{D} \mathrm{d}_{\text {norm }}$, shape index and curvedness for $\left(\mathrm{C}_{6} \mathrm{~N}_{2} \mathrm{H}_{7} \mathrm{~S}\right)_{2}\left[\mathrm{SbCl}_{4}\right] \mathrm{Cl}$ are illustrated in (Fig. 8), showing surfaces that have been mapped over $\mathrm{d}_{\text {norm }}$ ranges from -0.385 to $1.114 \AA$, shape index ranges from -0.997 to $0.998 \AA$, and curvedness ranges from -4.183 to $0.378 \AA$, respectively. The $d_{\text {norm }}$ mapping indicates that strong hydrogen bond interactions, such as $\mathrm{N}-\mathrm{H} \cdots \mathrm{Cl}$ hydrogen bonding between amino group and chloride appears as the main interaction between the complexes, seen as a bright red area in the Hirshfeld surfaces (Fig. 8a).

The superseding $\mathrm{H} \cdots \mathrm{Cl}$ interactions are viewed in Hirshfeld surfaces by the bright red area in Fig. 8a which appear as distinct spike in the 2D fingerprint plots (Fig. 9). Visible complementary regions are visible in the fingerprint plots where one molecule acts as a donor $\left(d_{e}>d_{i}\right)$ and the other as an acceptor $\left(\mathrm{d}_{\mathrm{e}}<\mathrm{d}_{\mathrm{i}}\right)$. The 2D fingerprint plots of the title compound (Fig. 9) point out the strong intermolecular contacts which are $\mathrm{Cl}-\mathrm{H}, \mathrm{N}-\mathrm{H}, \mathrm{C}-\mathrm{H}$ and $\mathrm{S}-\mathrm{H}$. In fact, the $\mathrm{H} \cdots \mathrm{Cl} / \mathrm{Cl} \cdots \mathrm{H}$ interactions are predominant in the title compound with the major contributions 50.8\% (Fig. 9). Moreover, the point in the $\left(\mathrm{d}_{\mathrm{e}}, \mathrm{d}_{\mathrm{i}}\right)$ range of $(1.58 \AA, 0.95 \AA)$ in the fingerprint plots are due to $\mathrm{N}-\mathrm{H} \cdots \mathrm{Cl}$ interactions. The other visible spots were attributed to $\mathrm{S} \cdots \mathrm{H} / \mathrm{H} \cdots \mathrm{S}$ contacts (16.5\%), the proportion of $\mathrm{H} \cdots \mathrm{H}$ interactions present $9.2 \%$, whereas, the relative contributions for $\mathrm{C} \cdots \mathrm{H} / \mathrm{H} \cdots \mathrm{C}, \mathrm{C} \cdots \mathrm{C}$ and $\mathrm{N} \cdots \mathrm{H} / \mathrm{H} \cdots \mathrm{N}$ contacts are $5 \%, 2.6 \%$ and $2.1 \%$ respectively.

Figure 10 shows the percentages of contributions for all contacts in the title compound.

This constitutes evidence that Van-Der-Waals forces can enhance the stabilization of the packing. The shape index is highly sensitive to very subtle changes in surface shape. Indeed, the shape index (S) is OD dimensionless surface property defined in terms of the two principal curvatures of the surface and can be used to distinguish complementary hollows $(\mathrm{S}=-1.0$; concave region; red colored) and bumps ( $\mathrm{S}=+1.0$; convex region; blue colored) where two molecular Hirshfeld surfaces come into contact [18].Generally, the red and blue adjacent strangles on a shape index map provide $\pi-\pi$ interaction information $[15,18,40]$. However, in this compound the $\pi-\pi$ interactions were absent as presented in Fig. 8b. Thus, the Hirshfeld surface confirms the absence of the $\pi-\pi$ stacking interactions in organic cations. The curvedness is a measure of the shape of the surface area of the molecule. The flat areas of the surface as revealed in Fig. 8c correspond to low values of curvedness, while sharp 
Fig. 9 Fingerprint plot (de vs. di) of $\left(\mathrm{C}_{6} \mathrm{H}_{7} \mathrm{~N}_{2} \mathrm{~S}\right)_{2}\left[\mathrm{SbCl}_{4}\right] \mathrm{Cl}$ involving $\mathrm{C} \cdots \mathrm{C}$ interactions

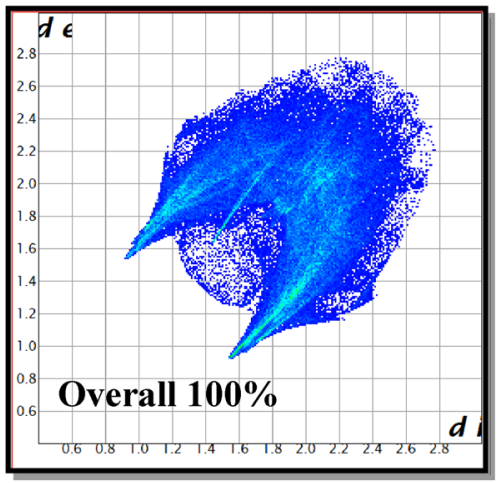

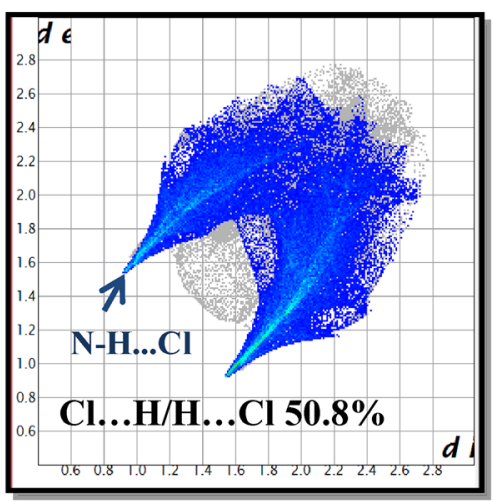

(a)

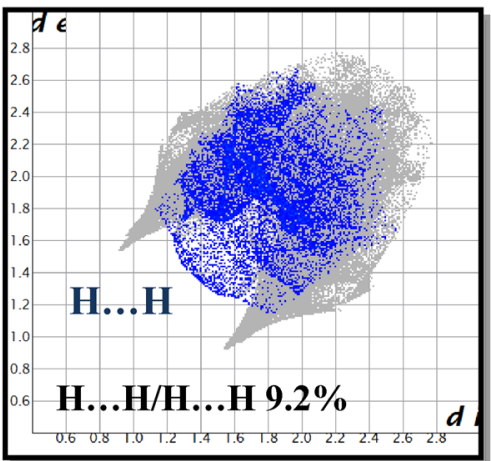

(c)

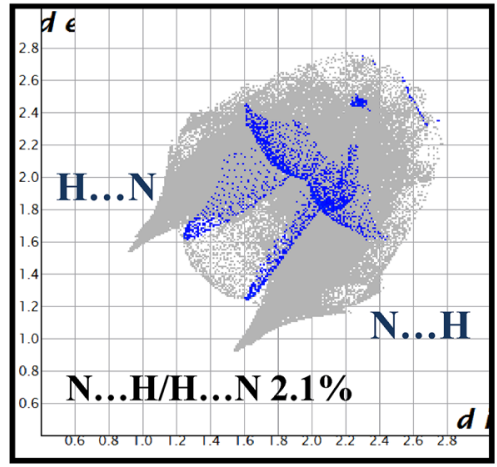

(e)

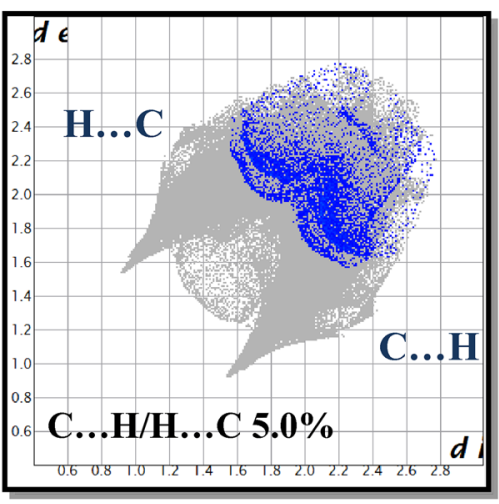

(b)

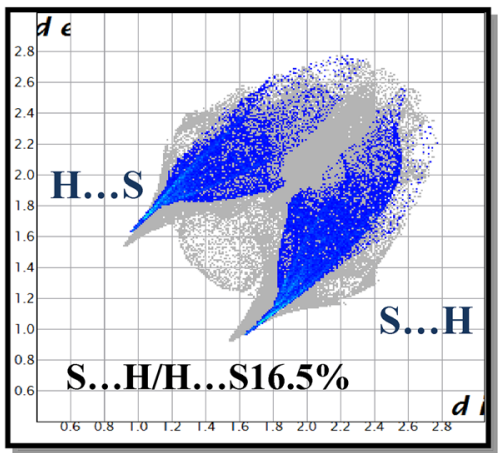

(d)

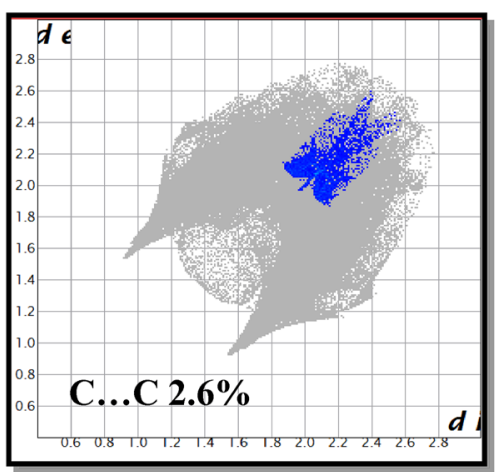

(f) 


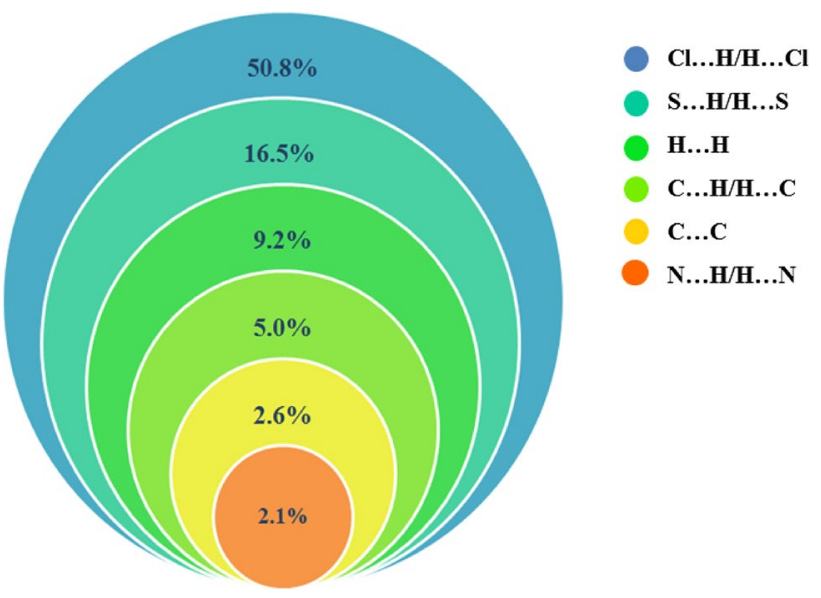

Fig. 10 Percentage contributions of the various intermolecular contacts contributing to the Hirshfeld surfaces of $\left(\mathrm{C}_{6} \mathrm{H}_{7} \mathrm{~N}_{2} \mathrm{~S}\right)_{2}\left[\mathrm{SbCl}_{4}\right] \mathrm{Cl}$

curvature areas correspond to high values of curvedness and usually tend to divide the surface into patches, indicating interactions between neighboring molecules. Moreover, the small range of area and light color on the surface indicate a weaker and longer contact other than hydrogen bonds. The large flat region which delineated by a blue outline refers to the $\pi-\pi$ staking interactions. It is obvious that the curvedness of the complex reveals the absence of $\pi-\pi$ stacking interactions in this complex Fig. 8c [41, 42].

\section{Conclusion}

The zero-dimensional hybrid compound $\left(\mathrm{C}_{6} \mathrm{~N}_{2} \mathrm{H}_{7} \mathrm{~S}\right)_{2}\left[\mathrm{SbCl}_{4}\right]$ $\mathrm{Cl}$ structure consists of discrete $\left[\mathrm{SbCl}_{4}\right]^{-}$anion and two isolated chloride $\mathrm{Cl}$ anions. The atomic arrangement shows an alternations of organic and inorganic layers parallel to the [001] direction which are themselves linked via hydrogen bonds involving $\mathrm{Cl}^{-}$anions $(\mathrm{N}-\mathrm{H} \cdots \mathrm{Cl})$ forming a selfassembled zero-dimensional network. Fingerprint plots based on Hirshfeld surfaces analysis shows the various types of intermolecular interactions in this material.

In addition, the vibrational modes of this structure were studied by infrared spectroscopy, which were assigned by comparison with similar compounds.

\section{Supplementary Materials}

CCDC 1888302 include supplementary crystallographic data for this paper. This data can be obtained free of charge via http://www.ccdc.cam.ac.uk/conts/retrieving.html, or from the Cambridge Crystallographic Data Centre, 12 Union Rood, Cambridge CB2 1EZ, UK (Fax: (international): +44 1223/336 033; e-mail: deposit@ccdc.cam.ac.uk).
Funding Funding was provided by 4 .

Open Access This article is distributed under the terms of the Creative Commons Attribution 4.0 International License (http://creativeco mmons.org/licenses/by/4.0/), which permits unrestricted use, distribution, and reproduction in any medium, provided you give appropriate credit to the original author(s) and the source, provide a link to the Creative Commons license, and indicate if changes were made.

\section{References}

1. D.B. Mitzi, Prog. Inorg. Chem. 48, 1 (1999)

2. H. Dammak, S. Triki, A. Mlayah, Y. Abid, H. Feki, J. Lumin. 166, $180(2015)$

3. A. Lipka, D. Mootz, Z. Anorg, Allg. Chem. 440, 231 (1978)

4. K. Kozawa, T. Uchicha, Acta Crystallogr. C 46, 1006 (1990)

5. M. Bujak, J. Zaleski, J. Mol. Struct. 647, 121 (2003)

6. J. Tarasiewicz, R. Jakubas, J. Baran, J. Vib. Spectrosc. 18, 203 (1998)

7. A. Samet, H. Boughzala, H. Khemakhem, Y. Abid, J. Mol. Struct. 984, 23 (2010)

8. B. Wenhua, N. Leblanc, N. Mercier, P. Auban-Senzier, C. Pasquier, Chem. Mater. 21, 4099 (2009)

9. R. Jakubas, L. Sobczyk, Phase Transit. 20, 163 (1990)

10. M. Hall, M. Nunn, M.J. Begley, D.B. Sowerby, J. Chem. Soc. Dalton Trans. 6, 1231 (1986)

11. S.K. Wolff, D.J. Grimwood, J.J. Mckinnon, D. Jayatilaka, M.A. Spackman, Crystal Explorer 2.0 (University of Western Australia, Perth, Australia, 2007)

12. S.K. Seth, D. Sarkar, A.D. Jana, T. Kar, J. Cryst. Growth Des. 11, 4837 (2011)

13. M.A. Spackman, J.J. McKinnon, D. Jayatilaka, CrystEngComm 10, 377 (2008)

14. M.A. Spackman, P.G. Byrom, Chem. Phys. Lett. 267, 215 (1997)

15. M.A. Spackman, D. Jayatilaka, CrystEngComm 11, 19 (2009)

16. A.L. Rohl, M. Moret, W. Kaminsky, K. Clabor, J.J. Mckinnon, B. Kahr, Cryst. Growth Des. 8, 45 (2008)

17. A. Parkin, G. Barr, W. Dong, C.J. Gilmore, D. Jayatilaka, J.J. Mickinnon, M.A. Spackman, C.C. Wilson, CrystEngComm 9, 648 (2007)

18. M.A. Spackman, J. McKinnon, CrystEngComm 4, 378 (2002)

19. J.J. Koenderink, A.J. van Doorn, Image Vis. Comput. 10, 557 (1992)

20. S.K. Wolff, D.J. Grimwood, J.J. Mckinnon, M.J. Turner, D. Jayatilaka, M.A. Spackman, Crystal Explorer 2.2 (University of Western Australia, Crawley, 2010)

21. S.K. Seth, D. Sarkar, A.D. Jana, T. Kar, J. Cryst, Growth Des. 11, 4837 (2011)

22. G.M. Sheldrick, SHELXS-2013, Programs for Crystal Solution (University of Gottingen, Germany, 2013)

23. G.M. Sheldrick, SHELXL-2013, Programs for Crystal Structure Refinement (University of Göttingen, Germany, 2013)

24. K. Brandenburg, Diamond Version 2.0 Impact GbR, Bonn, Germany (1998)

25. S. Shit, C. Marshner, S. Mitra, Acta. Chim. 63, 129 (2016)

26. C. Hrizi, C. Chaker, S. Chaabouni, Ionics 17, 545 (2011)

27. Y. Baklouti, N. Chaari, H. Feki, N. Chniba-Boudjada, F. Zouar, J. Spectrochim. Acta Part A 136, 397 (2015)

28. D. Fredj, C. Ben Hassen, S. Elleuch, H. Feki, N. Chniba Boudjada, T. Mhiri, M. Boujelbene, J. Mater. Res. Bull. 85, 23 (2017)

29. H. Dammak, H. Feki, H. Boughzala, Y. Abid, Spectrochim. Acta Part A 137, 1235 (2015) 
30. C. BenHassen, T. Dammak, N. Chniba-Boudjada, T. Mhiri, M. Boujelbene, J. Mol. Struct. 1127, 43 (2017)

31. C. Hrizi, N. Chaari, Y. Abid, N. Chniba Boudjaba, S. Chaabouni, Polyhedron 46, 41 (2012)

32. S. Chaouachi, S. Elleuch, B. Hamdi, R. Zouari, J. Mol. Struct. 1125, 149 (2016)

33. H. Ferjani, H. Boughzala, A. Driss, J. Crystallogr. 8, 2 (2013)

34. Z. Aloui, V. Ferretti, S. Abid, F. Lefebvre, M. Rzaigui, C. Ben Nasr, J. Mol. Struct. 1097, 166 (2015)

35. A. Vogler, H. Nikol, Pure Appl. Chem. 64, 1311 (1992)

36. H. Dammak, A. Yangui, S. Triki, Y. Abid, H. Feki, J. Lumin. 161, $214(2015)$

37. H. Ferjani, H. Boughzala, J. Mater. 2013, 8 (2014)

38. A. Samet, A. Ben Ahmed, A. Mlayah, H. Boughzala, E.K. Hlil, Y. Abid, J. Mol. Struct. 977, 72 (2010)
39. A. Vogler, H. Nikol, Comments Inorg. Chem. 14, 245 (1993)

40. R.S. Bitzer, C. Lorenzo, M. Horner, A.C. Marco Nascimento, C.A.L. Filgueiras, J. Mol. Struct. 1130, 165 (2017)

41. Y.H. Luo, G.G. Wu, S.L. Mao, B.W. Sun, Inorg. Chim. Acta 397, 1 (2013)

42. Y. Li, C.G. Zhang, L.Y. Cai, Z.-X. Wang, J. Coord. Chem. 66, $3100(2013)$

Publisher's Note Springer Nature remains neutral with regard to jurisdictional claims in published maps and institutional affiliations. 